\title{
Konversi Bahasa Indonesia Ke BISINDO Menggunakan JASigning dengan Metode Lookup Table
}

\author{
Wensi Sekarsari $^{\# 1}$, Arif Bijaksana Putra Negara ${ }^{* 2}$, Rudy Dwi Nyoto ${ }^{\# 3}$

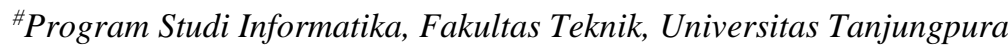 \\ Jl. Prof. Dr. H.Hadari Nawawi, Pontianak, Kalimantan Barat, 78115 \\ ${ }^{1}$ wensisekarsariestudent.untan.ac.id \\ 2arifbpneinformatika.untan.ac.id \\ ${ }^{3}$ rudydneinformatika.untan.ac.id
}

\begin{abstract}
Abstrak
Keterbatasan jumlah juru bahasa isyarat untuk BISINDO dapat menghambat terwujudnya proses komunikasi, baik antara Teman dengar dan Teman Tuli maupun sebaliknya. Untuk mengatasi permasalahan tersebut penelitian yang dilakukan bertujuan membuat sistem yang langsung dapat mengkonversi masukan berupa teks Bahasa Indonesia (yang sebelumnya telah dibuat juga kedalam bentuk HamNoSys) menjadi gerakan isyarat BISINDO yang dapat dianimasikan dengan menggunakan JASigning. Sistem konversi yang dirancang sangat bergantung pada algoritma pencarian dan pencocokan kata dengan simbol HamNoSys pada basis data sehingga metode Lookup Table digunakan untuk menyederhanakan komputasi dan mempermudah proses konversi. Kata - kata yang digunakan untuk penelitian diambil berdasarkan frekuensi kata yang paling sering muncul dalam buku cerita "Asal Mula Kota Pontianak". Kata - kata ini kemudian akan disusun menjadi kalimat uji yang akan digerakkan dengan menggunakan animasi 3D JASigning. Kualitas gerakan isyarat yang dihasilkan dapat diukur dengan aspek intelligibility dan acceptability dengan WER dan Skala likert sebagai instrumen penilaiannya. Hasil pengujian menunjukkan terhadap 10 Kalimat yang diujikan WER mendapatkan skor $94 \%$ dan 9 dari 10 kalimat yang diujikan mendapatkan rentang skor likert 75\%-99\%, ini berarti sistem konversi yang dibangun sudah memiliki intelligibility dan acceptability yang tinggi untuk gerakan isyarat BISINDO yang dihasilkan.
\end{abstract}

Kata kunci: konversi, BISINDO, HamNoSys, JASigning, intelligibility dan acceptability

\section{Indonesian Text to BISINDO Convertion Using JASigning with Lookup Table Method}

\begin{abstract}
The limitation of language translators for BISINDO can hamper the realization of the communication process, both between fully hearing person and hearing impaired person (Deaf) vice versa. To overcome these problems, the research conducted aims to create a system that can convert input in the form of Indonesian text (that has been previously made in the form of HamNoSys) into BISINDO gesture that can be animated using JASigning. The designed conversion system relies heavily on search and matching algorithms between words and the HamNoSys symbol in the database, these makes Lookup Table method is used to simplify computing and ease the conversion process. The words used for the research were taken based on the frequency of the words that most often appear in the folklore book entitled "The Origin of the Pontianak City". These words will then be arranged into test sentences which will be gestured using 3D JASigning animation. The quality of the gesture produced can be measured by two aspects, intelligibility and acceptability with the Word Error Rate (WER) and likert scale as an assessment instrument. The test results show that from the 10 Sentences tested by WER, its received a score of $94 \%$ and 9 of the 10 sentences tested received Likert score range of $75 \%-99 \%$. This means that the conversion system designed had high intelligibility and acceptability for the generated BISINDO gesture.
\end{abstract}

Keywords: Conversion, BISINDO, HamNoSys, JASigning, Intelligibility and Acceptability

\section{Pendahuluan}

Bahasa isyarat adalah bahasa utama yang digunakan oleh masyarakat yang tuli dalam berkomunikasi. Di Indonesia sendiri terdapat berbagai macam bahasa isyarat, namun yang paling umum digunakan adalah Sistem
Isyarat Bahasa Indonesia (SIBI) dan Bahasa Isyarat Indonesia (BISINDO). Penggunaan kedua bahasa ini berdasarkan tingkat responnya menghasilkan sebagian besar responden tunarungu menjawab sangat setuju dengan menggunakan BISINDO (48\%) dan setuju (43\%) dibanding dengan menggunakan SIBI yang sangat setuju 
(2\%) dan setuju (6\%)[1]. Dengan demikian dapat dikemukakan bahwa BISINDO lebih ramah digunakan tunarungu sebagai komunikasi dibandingkan SIBI.

Pada tahun 1994 - 1996 Kementerian Kesehatan mengadakan survey di 7 provinsi di Indonesia yang menyimpulkan bahwa sebanyak 0,1\% dari seluruh angka kelahiran akan mengalami ketulian Kongenital (Tuli sejak lahir). Hal ini berarti dari 1.000.000 kasus kelahiran maka 1000 diantaranya diperkirakan mengalami ketulian. Tingginya angka tersebut secara otomatis juga meningkatkan kebutuhan akan komunikasi yang baik bagi penderita ketulian agar mereka tetap dapat bersosialisasi dengan nyaman dan tidak merasa terisolir dalam masyarakat.

Komunikasi antara masyarakat tuli dan masyarakat umum idealnya membutuhkan kehadiran seorang penerjemah yaitu juru bahasa isyarat. Menurut data yang dihimpun oleh Pusat Layanan Jurubahasa (PLJ) pada tahun 2016, Indonesia hanya memiliki 34 orang juru bahasa isyarat sementara itu berdasarkan data proyeksi dari Badan Perencanaan Pembangunan Nasional angka kelahiran total tahun 2015-2020 berkisar 9,6 juta jiwa [2] dan jika dihitung dengan persentase seperti diatas maka pada rentang tahun tersebut sebesar $0,1 \%$ atau 9.600 jiwa dari 9,6 juta jiwa diperkirakan akan mengalami ketulian. Timpangnya jumlah juru bahasa yang tersedia dengan jumlah masyarakat yang lahir dengan kondisi tuli ini akan menghambat komunikasi mereka dengan masyarakat.

Seiring perkembangan teknologi, permasalahan minimnya juru bahasa isyarat sudah dapat diselesaikan dengan sistem konversi seperti pada penelitian [3]-[6] yang memberikan masukkan berupa ucapan ataupun teks yang kemudian divisualisasikan gerakan isyaratnya menggunakan animasi 3D ataupun video. Namun, sistem konversi yang sudah ada tersebut hanya tersedia dalam bahasa isyarat Inggris, Amerika, India dan SIBI, sedangkan untuk BISINDO sendiri belum terdapat alternatif untuk permasalahan minimnya juru bahasa isyarat sehingga penelitian yang dilakukan bertujuan untuk menghasilkan sistem yang dapat mengubah teks Bahasa Indonesia menjadi Bahasa Isyarat Indonesia (BISINDO) menggunakan JASigning dengan metode Lookup Table.

\section{TINJAUAN PUSTAKA}

\section{A. BISINDO}

BISINDO adalah bahasa isyarat yang diciptakan dan dicetuskan oleh seorang penyandang tunarungu yaitu Dimyati Hakim (Ketua DPP PERTRI). Penelitian yang pertama kali dilakukan oleh Dimyati Hakim adalah membedakan bahasa isyarat di Indonesia berdasarkan bentuk struktural dan konseptual dengan memaparkan fungsi, maksud, tujuan, dan lingkup penggunaanya.

\section{B. HamNoSys}

Sistem Notasi Hamburg (HamNoSys) adalah sistem yang digunakan untuk menuliskan isyarat, seperti huruf fonetik yang digunakan untuk bahasa lisan. HamNoSys mampu menggambarkan semua isyarat yang digunakan dalam semua bahasa isyarat. Itu tidak bergantung pada perbedaan percakapan bahasa isyarat dari satu negara ke negara lainnya dan karenanya itu bisa digunakan secara internasional [7].

Notasi HamNoSys (Gambar 1) untuk satu isyarat terdiri dari deskripsi postur awal (hand shapes, hand orientation dan location) ditambah dengan tindakan mengubah postur tersebut secara berurutan atau sejajar. Spesifikasi symmetry operator, nonmanual features dan lokasi adalah optional. Symmetry operator digunakan apabila isyarat menggunakan kedua tangan. Nonmanual features digunakan apabila terdapat penggunaan selain tangan seperti ekspresi wajah, gerakan mulut, gerakan kepala. Jika spesifikasi lokasi tidak ada, maka lokasi akan diasumsikan default.

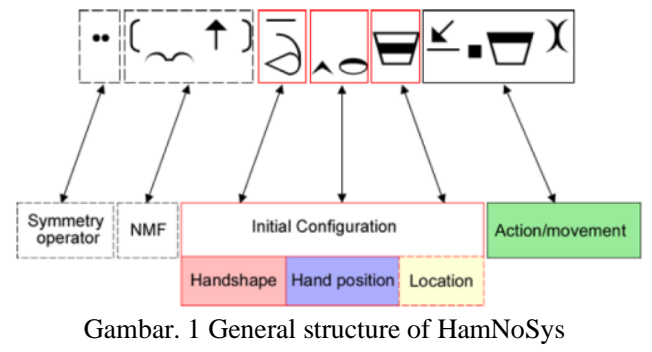

\section{Sigml}

SiGML adalah Signing Gesture Mark-up Language. SiGML ini menggambarkan simbol HamNoSys ke dalam bentuk tag XML (Extensible Markup Language). Representasi SiGML yang dibuat dari notasi HamNoSys tentang bahasa isyarat dapat dibaca oleh perangkat lunak rendering 3D [8].

SiGML dikembangkan di East Anglia (UEA) untuk menentukan urutan dari isyarat. Penulisan SiGML berbentuk XML dan menggunakan tag yang berbeda untuk merepresentasikan simbol HamNoSys yang sesuai. Hal ini diberikan sebagai input ke server animasi untuk menghasilkan frames yang mana mendefinisikan pose dari avatar [9]. Tabel I Menunjukkan contoh SiGML dan HamNoSys dari kata "Jealous" dalam British Sign Language (BSL).

TABEL I

NOTASI SIGML DAN HAMNOSYS DARI KATA JEALOUS.

\begin{tabular}{|c|c|}
\hline HamNoSys & SiGML \\
\hline $\begin{array}{l}\square \square \text { Bentuk Tangan } \\
\square \quad \text { Extended Finger } \\
\text { Orientation } \\
\square \quad \text { Orientasi Telapak } \\
\text { Tangan } \\
\square \quad \text { Lokasi Tangan } \\
\square \quad \text { Kedekatan Tangan } \\
\square \quad \text { Gerakan Tangan }\end{array}$ & 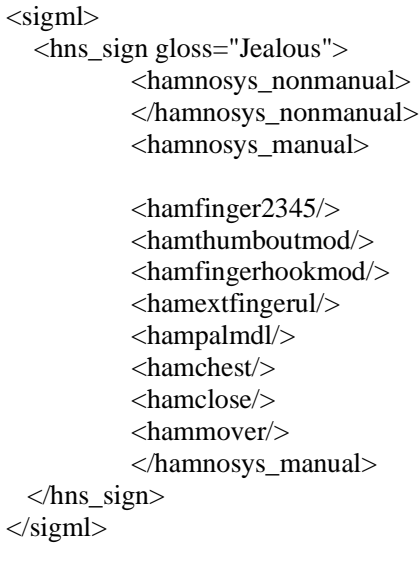 \\
\hline
\end{tabular}




\section{JASigning}

JASigning (Java Avatar Signing) adalah avatar sintetik untuk isyarat tuli, yang ditulis dalam bahasa pemrograman Java [10]. JASigning ini didasarkan pada teknik animasi komputer 3D konvensional sehingga pengguna memiliki avatar virtual yang dapat melakukan gerakan isyarat. JASigning menggunakan SiGML sebagai masukkan untuk avatar virtual yang akan menghasilkan keluaran berupa representasi gerakan isyarat yang dilakukan oleh avatar virtual tersebut.

\section{E. Lookup Table}

Lookup Table adalah Array atau matriks data yang berisi item yang dicari. Tabel pencarian ini dapat diatur sebagai pasangan nilai kunci yang merupakan item atau data yang dicari (looked up) dan nilainya adalah data aktual atau petunjuk ke tempat data berada. Tidak jarang, tabel pencarian hanya berisi item data (hanya nilai, bukan pasangan nilai kunci) [11]. Lookup Table secara umum adalah tabel yang berisi daftar data yang tetap. Data ini tidak sering berubah dan dapat dijadikan sebuah referensi untuk pencarian data jika diperlukan. Contoh data ini dapat berupa daftar produk, jenis kategori, daftar pemasok, nama negara, kode pos, kode area telepon, dll.

Sebagai contoh; Pada penelitian yang akan dilakukan, lookup table digunakan sebagai tabel referensi untuk konversi simbol menjadi bentuk tag XML sehingga saat program menerima input berupa notasi hamnosys yang terdiri atas simbol - simbol maka sistem dapat secara langsung menentukan bentuk SIGML nya tanpa perlu di input secara manual bentuk SIGML untuk notasi tersebut. Ilustrasi ini dapat dilihat pada Gambar 2.

\begin{tabular}{|c|c|c|c|c|c|c|}
\hline Kalimat & Notasi Ham NoSys & \multicolumn{2}{|c|}{ Lookup Table } & & \multicolumn{2}{|r|}{ SIGML } \\
\hline 'saya' & $0,0 \Xi^{x}$ & 0 & $<$ hamflathand/> & \multirow{5}{*}{$D$} & \multirow{3}{*}{\multicolumn{2}{|c|}{$\begin{array}{l}\text { <sigml> } \\
\text { <hamflathand/> } \\
\text { <hamextfingerul/> } \\
\text { <hampalml/> } \\
\text { <hamchest/> } \\
\text { <hamtouch/> }\end{array}$}} \\
\hline & & r & <hamextingerul/> & & & \\
\hline & & 0 & <hampalml/> & & & \\
\hline & & 目 & <hamchest/> & & \multirow{2}{*}{ </sigml> } & \\
\hline & & $x$ & <hamtouch/> & & & \\
\hline
\end{tabular}

Gambar. 2 Contoh lookup table

\section{F. Pengujian Kualitas Isyarat}

Sangat penting bahwa sistem menyampaikan informasi yang berguna dengan cara yang bermanfaat dan dapat diterima oleh pengguna tuna rungu. Mengukur kualitas dari suatu isyarat dapat menjadi Salah satu metode evaluasi untuk mengetahui seberapa besar manfaat dan kegunaan yang didapat dari sistem yang diteliti. Dua aspek utama yang dapat dijadikan kriteria pengukuran kualitas suatu isyarat adalah Intelligibility dan Acceptability [3].

\section{Intelligibility}

Menurut bahasa intelligibility berarti kejelasan atas suatu hal. Mengukur aspek kejelasan dalam komunikasi bertujuan untuk mengetahui seberapa mudah suatu ucapan dapat dipahami oleh audience. Seperti penelitian yang dilakukan oleh Guntoro [12] yang mengukur intelligibility dari model TTS (Text To Speech) yang mereka ajukan menggunakan Word Error Rate.
Bagaimanapun juga, di dalam bahasa isyarat komunikasi yang berlangsung lebih banyak menggunakan gerakan dibandingkan dengan ucapan oleh karena itu pengunaan ucapan digantikan dengan komunikasi melalui bahasa tubuh sehingga pengukuran aspek kejelasan pun akan dinilai dari seberapa mudah target audience untuk memahami gerakan yang diperlihatkan. Aspek ini juga akan diukur menggunakan metode WER.

2. Acceptability

Pengukuran kualitas isyarat berdasarkan aspek intelligibility sebenarnya sudah cukup untuk menilai apakah gerakan isyarat yang dihasilkan sudah cukup baik (jelas) atau tidak. Namun sayangnya penilaian berdasarkan aspek intelligibility ini hanya mengukur dari sisi objektif penelitian saja, dalam artian hasil yang didapat itu murni hanya dari membandingkan tingkat error dari kata dalam kalimat yang diujikan tanpa memperdulikan sisi subjektif nya, yaitu si target audience atau sahabat Tuli itu sendiri. Oleh karena itu pengukuran dari sisi subjektif juga perlu dilakukan agar hasil yang didapat lebih komperhensif. Penelitian [3] mengajukan pengukuran aspek "acceptability" sebagai salah satu standar pengukuran yang bersifat subjektif untuk kualitas isyarat. Aspek ini juga akan diukur menggunakan metode skala likert.

\section{G. Word Error Rate (WER)}

Setiap kata dalam kalimat yang dihipotesiskan dibandingkan dengan kalimat referensi dan setiap kata yang tidak cocok (dimasukkan, dihapus atau diganti) dihitung sebagai kesalahan dan dibagi dengan jumlah total kata dalam kalimat referensi [13].Penelitian yang diajukan menggunakan pengujian ini untuk membandingan gerakan JASigning dalam merepresentasikan isyarat BISINDO dengan kalimat teks pengujian. Kemudian hasil perbandingan tersebut dihitung menggunakan Persamaan 1.

$\mathrm{WER}=\frac{S+D+I}{N_{r}}$

(1)

Keterangan.

$\mathrm{S}=$ jumlah kata yang terganti pada kalimat yang telah didengarkan dan ditulis kembali

$\mathrm{D}=$ jumlah kata yang terhapus

I = jumlah kata yang tertambah

$\mathrm{Nr}=$ jumlah kata pada kalimat

H. Skala Likert

Skala likert digunakan untuk menganalisis hasil dari pengumpulan data uji menggunakan kuesioner. penggunaan skala pengukuran yang tepat pada kuesioner, dalam hal datanya; nominal, ordinal, interval dan ratio lebih disarankan untuk menggunakan pertanyaan tertutup. Skala dapat berjumlah genap atau ganjil. Untuk penelitian di Indonesia disarankan menggunakan skala Likert genap misalnya dengan 4 tingkat (berarti skala genap) yaitu: 1 (sangat setuju), 2 (setuju), 3 (kurang setuju) dan 4 (tidak setuju). Sebab terdapat kecenderungan bahwa individu di Indonesia cenderung bersikap netral, apabila demikian responden lebih mempunyai sikap kepada setuju atau tidak setuju. Namun apabila menggunakan skala Likert ganjil, misalnya lima tingkat skala Likert seperti: 1 
(sangat setuju), 2 (setuju), 3 (netral), 4 (kurang setuju) dan 5 (tidak setuju).maka individu di Indonesia dikhawatirkan akan cenderung memilih tiga (yang mencerminkan sikap netral) [14].

Persentase dari tiap jawaban responden dapat dihitung menggunakan Persamaan 2.

$$
Y=\frac{X}{\text { Skor ideal }} \times 100 \%
$$

Keterangan :

$\mathrm{Y}=$ Nilai persentase yang dicari

$\mathrm{X}=$ Jumlah nilai kategori jawaban dikalikan dengan frekuensi

$$
\left(\sum=\mathrm{N} . \mathrm{R}\right)
$$

$\mathrm{N}=$ Nilai dari setiap jawaban

$\mathrm{R}=$ Frekuensi

Skor ideal $=$ Nilai tertinggi dikalikan dengan jumlah sampel

\section{METODOLOGI PENELITIAN}

Langkah-langkah penelitian yang dilakukan pada penelitian ini dapat dilihat pada Gambar 3 sebagai berikut:

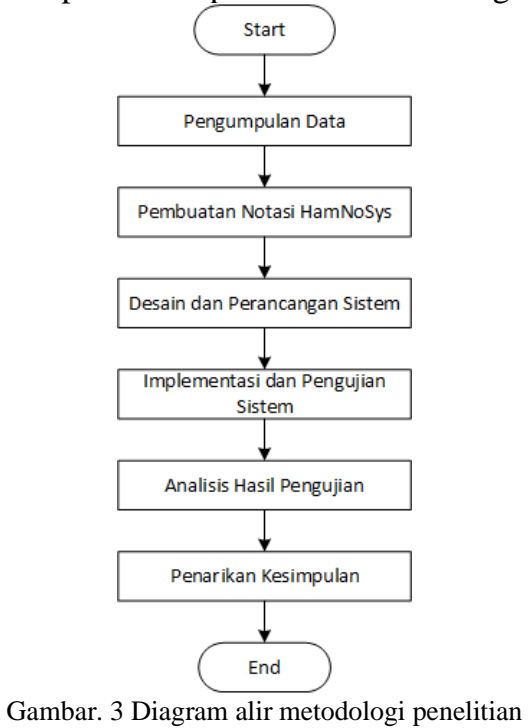

Berdasarkan Gambar .. dapat dijelaskan metodologi penelitian sebagai berikut:

\section{A. Pengumpulan Data}

Pengumpulan data dilakukan dengan menggunakan beberapa metode-metode seperti FGD, wawancara, dan Kuesioner. Sebelum melakukan pengumpulan data dengan metode tersebut, dilakukan pengumpulan data awal berupa kata yang akan di terjemahkan dan disusun ke dalam basis data terlebih dahulu. Kata tersebut di dapat dari frekuensi kata yang paling sering muncul dalam buku cerita Asal Mula Kota Pontianak. Langkah selanjutnya adalah melakukan pengumpulan informasi menggunakan metode FGD yang dilakukan dengan saling bertukar pendapat mengenai berbagai opini dan saran untuk melakukan penelitian. Melalui FGD dapat diketahui alasan, motivasi, argumentasi atau dasar dari pendapat seseorang atau kelompok. Namun, untuk memberi nilai tambah pada hasil suatu FGD agar dapat menjadi acuan dalam kesimpulan hasil penelitian, maka hasil FGD perlu disertai data pendukung atau ditindaklanjuti dengan metode kuantitatif [15].

Penelitian dilanjutkan dengan pengambilan data dengan cara dokumentasi visual, dimana narasumber akan direkam saat mengisyaratkan kata yang telah dipersiapkan pada pengumpulan data sebelumnya.

Pengumpulan data dengan menggunakan metode wawancara dan kuesioner dilakukan untuk membantu proses pengujian dimana hasil dari pengujian kualitatif ini akan diolah menggunakan pengujian kuantitatif berupa WER dan Skala likert yang hasilnya dapat di analisis dan ditarik kesimpulan.

\section{B. Pembuatan Notasi HamNoSys}

Kata yang akan dibuat notasi HamNoSys didapatkan pada pengumpulan data awal yakni frekuensi kata yang paling sering muncul di dalam buku cerita Asal Mula Kota Pontianak. Notasi HamNoSys akan dibuat berdasarkan dokumentasi visual berupa rekaman video yang telah di ambil dengan narasumber. Pergerakan tangan narasumber dari video akan diamati dengan perlahan kemudian dibuat notasi HamNoSys yang dapat merepresentasikannya. Setelah didapatkan notasi HamNoSys untuk seluruh isyarat pada rekaman yang diperlukan maka notasi akan disusun ke dalam tabel HamNoSys BISINDO. Berikut adalah tabel contoh BISINDO HamNoSys yang dapat dilihat pada Tabel II.

TABEL II

\begin{tabular}{|c|c|c|c|}
\hline No. & Bisindo & HamNoSys & Kategori \\
\hline 1. & A & $\left.=-\bar{p}_{\wedge 0}\left[\theta^{2}+\theta^{2}\right] x_{\theta}\right) x$ & Abjad \\
\hline 2. & Saya & $0,0 \theta^{x}$ & Kata \\
\hline
\end{tabular}

CONTOH HAMNOSYS BISINDO

\section{Perancangan Sistem}

Terdapat dua proses yang terjadi di dalam sistem konversi seperti terlihat pada Gambar 4.

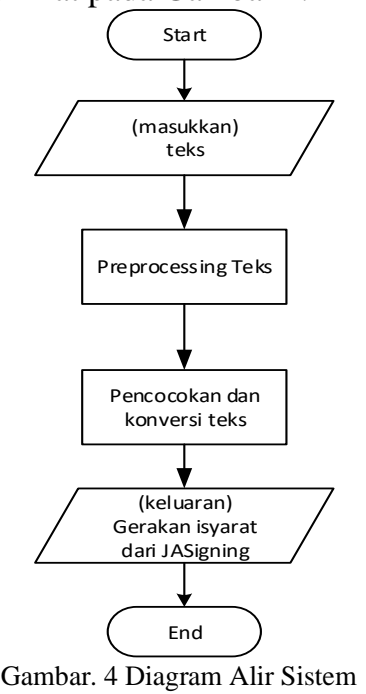

1) Preprocessing Text : Tahap ini memproses masukkan pengguna sehingga dapat digunakan untuk proses selanjutnya. Adapun proses-proses yang terjadi pada tahapan ini adalah case folding, tokenisasi, remove 
punctuation, eliminating dan stemming seperti pada Gambar 5.

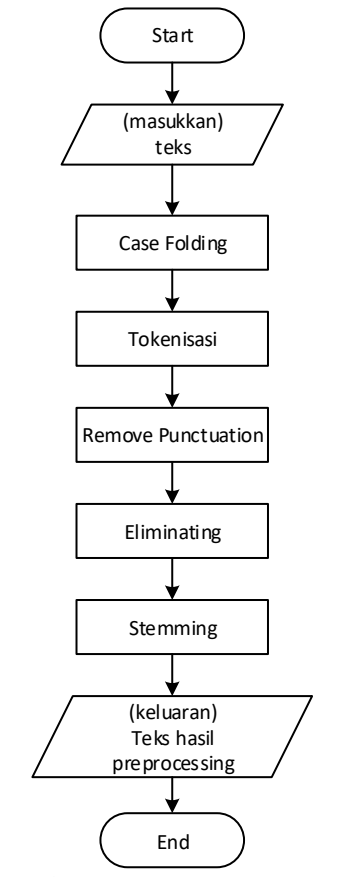

Gambar. 5 Preprocessing Text

Contoh masukkan pengguna "Saya ingin seperti burung yang melihat ke sini itu!!!”. Pertama-tama masukkan akan diproses pada tahap case folding yang menghasilkan pengecilan huruf kapital yang terdapat dalam masukkan sehingga hasil pada proses ini adalah "saya ingin seperti burung yang melihat ke sini itu!!!”. Selanjutnya teks tersebut akan diproses pada tahapan tokenisasi untuk memecah kata menjadi array sehingga hasil pada proses ini adalah "saya, ingin, seperti, burung, yang, melihat, ke, sini, itu, !, !, !’. Selanjutnya hasil tokenisasi akan diproses pada tahapan remove punctuation untuk dihilangkan karakter berupa simbol yang tidak diperlukan sehingga hasil pada proses ini adalah "saya, ingin, seperti, burung, yang, melihat, ke, sini, itu". Selanjutnya hasil dari remove punctuation akan diproses pada tahapan elimiating dimana dalam BISINDO tidak memiliki kata sambung sehingga pada proses ini kata sambung akan dihilangkan dan hasil dari proses ini menjadi "saya, ingin, seperti, burung, melihat, sini, itu". Selanjutnya adalah proses terakhir dalam preprocessing text yakni stemming. Proses stemming dilakukan karena dalam BISINDO tidak terdapat imbuhan sehingga hasil dari proses ini adalah "saya, ingin seperti, burung, lihat, sini, itu".

2) Pencocokan dan Konversi Teks : Pada tahap pencocokan dan konversi teks, teks akan dicocokan satu persatu dengan record yang ada pada basis data sehingga menghasilkan perintah untuk menggerakan JASigning. Proses pencocokan dan konversi teks terdiri dari beberapa tahap yang dapat dilihat pada Gambar 6 .

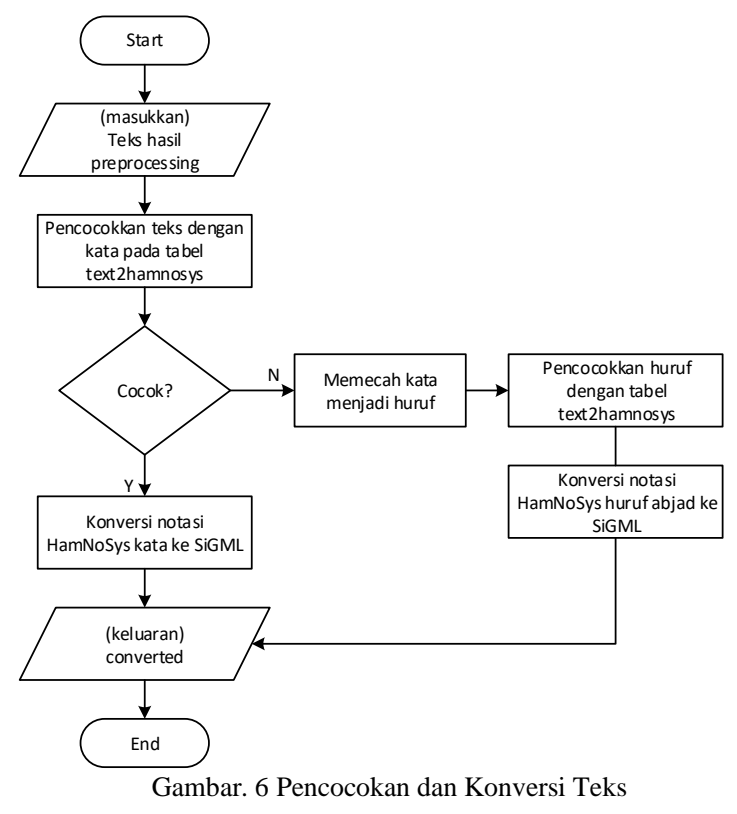

Seperti diagram alir penelitian yang terlihat pada Gambar 6, terdapat beberapa tahapan dalam proses pencocokan dan konversi teks yang dilakukan. Tahapan pertama adalah hasil dari proses preprocessing yang berupa himpunan kata akan dicocokkan dengan record basis data yang ada pada tabel hamnosys, record ini telah berisi daftar kata beserta notasi Hamnosys untuk kata tersebut. Jika sistem menemukan kecocokan untuk kata yang di masukkan maka notasi hamnosys pada record tersebut akan dikonversi ke dalam bentuk Sigml dengan memanfatkan table lookup seperti Gambar 7. Namun, jika tidak terdapat kecocokan maka kata akan tersebut akan di pecah menjadi huruf. Contohnya seperti terlihat pada Gambar 8. Proses selanjutnya yang akan dilakukan adalah mencocokan setiap huruf dari kata yang telah dipecah tadi dengan record yang ada pada tabel hamnosys. Huruf-huruf yang telah mendapatkan notasi HamNoSys kemudian akan dikonversi menjadi Sigml dengan memanfaatkan table lookup. Hasil akhir untuk kedua kondisi pencocokan adalah Sigml yang akan digunakan sebagai pembangkit gerakan isyarat dari JASigning.

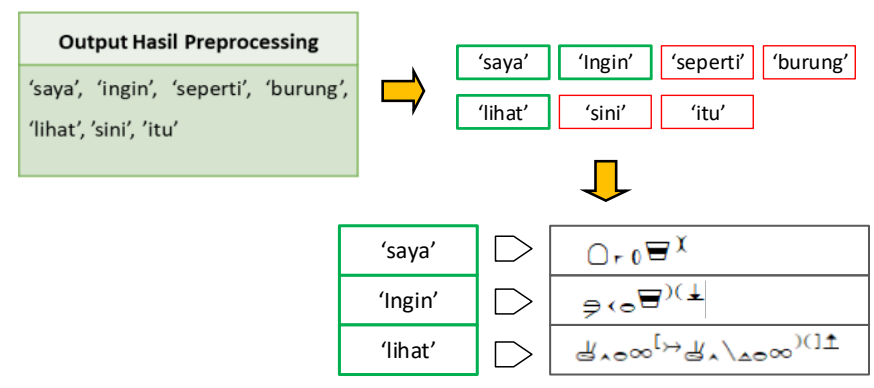

Gambar. 7 Pencocokan masukan dan record 


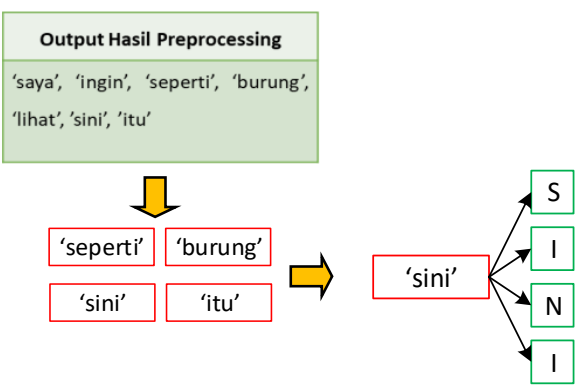

Gambar. 8 Pemecahan kata

\section{HASIL PENGUJIAN DAN ANALISIS}

Pengujian dilakukan dengan menguji kualitas dari gerakan isyarat yang digerakkan oleh JASigning. Pengujian kualitas gerakan isyarat terbagi menjadi 2 macam yaitu: Intelligibility (kejelasan) dan Acceptability (keberterimaan) [3]. Adapun beberapa instrumen yang akan digunakan adalah Word Error Rate (WER) dan analisis menggunakan skala likert.

Data uji yang akan digunakan dalam penelitian ini dibagi menjadi 3 variasi kalimat seperti terlihat pada Tabel III. Ketiga variasi kalimat tersebut diujikan kepada responden tuli dan JBI, dimana responden tuli akan melakukan pengujian hanya untuk variasi kalimat uji $\mathrm{c}$ sedangkan responden JBI akan menguji ketiga variasi kalimat uji tersebut. Hal ini dikarenakan hasil dari pengumpulan FGD bersama teman tuli dan JBI bahwa teman tuli keberatan dengan pengujian yang menggunakan variasi kalimat uji a dan b, sedangkan JBI tidak mempermasalahkan metode pengujian yang diajukan.

TABEL III

DAFTAR VARIASI KALIMAT UJI

\begin{tabular}{|c|c|c|l|}
\hline No. & $\begin{array}{c}\text { Nama } \\
\text { variasi }\end{array}$ & $\begin{array}{c}\text { Jumlah } \\
\text { kalimat }\end{array}$ & \multicolumn{1}{|c|}{ Keterangan } \\
\hline 1. & A & 10 & $\begin{array}{l}\text { Kalimat berisi kata yang tidak ada di } \\
\text { basis data (tiap kata dieja) }\end{array}$ \\
\hline 2. & B & 10 & $\begin{array}{l}\text { Kalimat berisi sebagian kata yang } \\
\text { ada di basis data (sebagian kata } \\
\text { dieja) }\end{array}$ \\
\hline 3 & C & 10 & $\begin{array}{l}\text { Kalimat berisi kata yang ada di basis } \\
\text { data (tidak ada yang dieja) }\end{array}$ \\
\hline
\end{tabular}

\section{A. Pengujian Intelligibility}

Pengujian intelligibility bertujuan untuk menguji tingkat kejelasan JASigning dalam mengisyaratkan BISINDO. Pengujian ini menggunakan wawancara sebagai pengumpulan data uji dan Word Error Rate (WER) sebagai instrumen pengukurannya. WER membandingkan gerakan JASigning dalam merepresentasikan isyarat BISINDO dengan kalimat teks pengujian.

Pengujian terbagi menjadi dua bagian yaitu pengujian pertama untuk responden tuli dan pengujian kedua untuk responden JBI. Hasil pengujian 10 kalimat uji variasi kalimat uji $\mathrm{C}$ terhadap 11 responden tuli dapat dilihat pada Tabel IV.

Hasil pengujian kedua untuk responden JBI terhadap ketiga variasi kalimat uji dapat dilihat pada Tabel V.
TABEL IV

Hasil PenguJian INTELLIGIBILITY RESPONDEN TULI

\begin{tabular}{|c|c|c|}
\hline No. & $\begin{array}{c}\text { Nama Inisial } \\
\text { Responden }\end{array}$ & Total WER \\
\hline 1 & WH & 0.05 \\
\hline 2 & LAT & 0.00 \\
\hline 3 & AMF & 0.05 \\
\hline 4 & WAP & 0.125 \\
\hline 5 & FAZ & 0.05 \\
\hline 6 & VT & 0.05 \\
\hline 7 & D & 0.025 \\
\hline 8 & GP & 0.00 \\
\hline 9 & ARPN & 0.1 \\
\hline 10 & E & 0.05 \\
\hline 11 & MM & 0.175 \\
\hline \multicolumn{2}{|c|}{ Rata - rata } & 0.06 \\
\hline \multicolumn{2}{|c|}{ Akurasi WER } & $94 \%$ \\
\hline
\end{tabular}

TABEL V

Hasil PENGuJian INTELLIGIBILITy RESPONDEN JBI

\begin{tabular}{|c|c|c|c|}
\hline & \multicolumn{3}{|c|}{ Variasi kalimat uji (dalam \%) } \\
\hline Pengujian & A & B & C \\
\hline Akurasi WER & 100 & 95 & 97.5 \\
\hline
\end{tabular}

Hasil analisis pengujian perbandingan kualitas gerakan isyarat berdasarkan responden tuli dan JBI terhadap variasi kalimat uji sebagai berikut:

1. Hasil pengujian intelligibility yang menggunakan instrumen WER terhadap teman tuli untuk variasi kalimat uji C adalah sebesar 94\%. Hasil ini menunjukkan bahwa tingkat kejelasan untuk gerakan isyarat JASigning sudah baik. Namun, Hal ini belum membuktikan bahwa sistem yang dirancang dapat diterima dengan baik. Oleh karena itu, pengujian dengan metode survey kepada responden tuli perlu untuk dilakukan karena dapat secara langsung mengukur kualitas gerakan isyarat yang di generate dari sisi subjektif penelitian.

2. Hasil pengujian intelligibility dengan instrument WER berdasarkan responden JBI menunjukkan akurasi yang paling tinggi pada kalimat uji A, dimana seluruh kata dalam sebuah kalimat dieja. Namun, pada kenyataannya penggunaan ejaan pada kalimat yang sudah terdapat gerakan isyaratnya sangat tidak difavoritkan oleh sahabat tuli itu sendiri. Hal ini dikarenakan WER hanya menguji kata-kata / objek tanpa memperhatikan sisi subjektif dalam dalam penelitian ini yaitu teman tuli. Oleh karena itu pengujian dengan WER saja tidak cukup untuk membuktikan bahwa sistem yang dirancang dapat diterima dengan baik. Untuk mengatasi hal tersebut pengujian dengan metode survey kepada responden tuli perlu untuk dilakukan, karena dapat secara langsung mengukur kualitas gerakan isyarat yang di generate dari sisi subjektif penelitian. 
3. Hasil pengujian intelligibility dengan instrumen WER berdasarkan responden JBI menunjukkan akurasi yang paling rendah pada kalimat uji $\mathrm{B}$, dimana kalimat ini merupakan gabungan antara isyarat untuk sebuah kata dan isyarat kata yang dieja satu persatu. Penggunaan kalimat seperti ini sedikit membingungkan responden dimana dia harus memahami mana isyarat sebuah kata dan mana isyarat yang mengeja sebuah kata. Oleh karena itu, pada saat pengujian menggunakan kalimat uji B terdapat 2 dari 10 kalimat yang mengalami penghapusan dan perubahan kata dari yang seharusnya.

4. Hasil pengujian intelligibility dengan instrumen WER berdasarkan responden JBI menunjukkan akurasi menengah untuk kalimat uji $\mathrm{C}$, dimana seluruh kata pada kalimat langsung dianimasikan dengan isyarat BISINDO-nya dengan kata lain tanpa ada pengejaan. Penggunaan kalimat seperti ini sangat disukai oleh teman tuli dalam kehidupan sehari-hari karena seluruh kata yang telah memiliki makna lebih mudah dipahami dibandingkan dengan variasi kalimat uji lainnya. Namun, isyarat dalam bahasa isyarat terkadang memiliki kemiripan sehingga makna yang dimaksudkan dan di sampaikan sedikit berbeda. Hal ini dapat dilihat pada kalimat 4 variasi c yang mengalami perubahan dari yang seharusnya pulang menjadi pergi. Hal tersebut dikarenakan bahasa isyarat untuk pergi dan pulang memiliki sedikit kemiripan namun jika diperhatikan dengan seksama sebenarnya isyarat untuk kedua kata tersebut berbeda.

\section{B. Pengujian Acceptability}

Pengujian Acceptability bertujuan untuk menganalisis tingkat keberterimaan responden tuli terhadap gerakan isyarat dari JASigning. Indikator yang digunakan untuk memberikan penilaian secara subjektif pada tingkat keberterimaan hasil gerakan isyarat adalah skala likert. Indikator penggunaan skala likert telah diubah menjadi bentuk bintang. Hal ini dikarenakan responden terbiasa untuk menilai sesuatu menggunakan bintang. Hasil pengujian acceptability dapat dilihat pada Tabel VI.

TABEL VI

Hasil Pengujian ACCEPTABILITY

\begin{tabular}{|c|c|c|c|c|c|c|}
\hline Kalimat & $\lambda$ & ک人从 & ज小 & $x \Delta x$ & $\begin{array}{l}\text { Total } \\
\text { Responden }\end{array}$ & $\begin{array}{c}\text { Hasil } \\
\text { Skala } \\
\text { Likert }\end{array}$ \\
\hline 1 & 1 & - & 5 & 5 & 11 & $82 \%$ \\
\hline 2 & 2 & 3 & 2 & 4 & 11 & $68 \%$ \\
\hline 3 & 1 & - & 6 & 4 & 11 & $79 \%$ \\
\hline 4 & 1 & 2 & 4 & 4 & 11 & $75 \%$ \\
\hline 5 & - & 4 & 1 & 6 & 11 & $79 \%$ \\
\hline 6 & - & 2 & 2 & 7 & 11 & $86 \%$ \\
\hline 7 & 1 & 2 & 1 & 7 & 11 & $82 \%$ \\
\hline 8 & 1 & - & 4 & 6 & 11 & $84 \%$ \\
\hline 9 & 1 & 1 & - & 9 & 11 & $89 \%$ \\
\hline 10 & - & 4 & 1 & 6 & 11 & $79 \%$ \\
\hline
\end{tabular}

Berdasarkan Tabel IV untuk mempermudah penafsiran hasil skala likert digunakan parameter dari [..] dengan $0 \%$ (tidak ada yang menerima), 1-24\% (sebagian kecil menerima), 25-49\% (kurang dari setengahnya menerima), $50 \%$ (setengahnya menerima), 51-74\% (lebih dari setengahnya menerima), $75-99 \%$ (sebagian besar menerima) dan $100 \%$ (seluruhnya menerima).

Hasil analisis berdasarkan Tabel IV dan parameter penafsiran yang digunakan sebanyak 9 dari 10 kalimat yang diujikan terhadap responden tuli mendapatkan skor dengan range $75-99 \%$ yang berarti sebagian besar menerima dengan baik gerakan isyarat yang dihasilkan. Hanya 1 kalimat yang mendapatkan skor $68 \%$ dan masuk dalam rentang skor $51-74 \%$ (lebih dari setengahnya menerima) yaitu kalimat nomor 2 (dua). Hal ini disebabkan kalimat nomor 2 terdapat kata - kata seperti 'tidak ingin', dimana gerakan akan di-generate per kata, berarti menjadi gerakan 'tidak' dan 'ingin' padahal dalam kenyataan nya kata 'tidak ingin' adalah satu kesatuan. Hal ini akan memunculkan makna yang saling bertentangan dan membuat responden tidak begitu nyaman dengan gerakan sehingga memiliki rate skor paling rendah.

\section{KESIMPULAN}

Berdasarkan hasil analisis dan pengujian terhadap sistem "Konversi Bahasa Indonesia ke BISINDO menggunakan JASigning dengan metode Lookup Table", maka dapat ditarik kesimpulan sebagai berikut:

1. Berdasarkan pengujian Intelligibility dari responden tuli, variasi kalimat uji c memiliki tingkat keakurasian sebesar $94 \%$. Hal ini menunjukkan bahwa isyarat yang digerakkan oleh JASigning sudah jelas dan dapat dipahami oleh pengguna.

2. Berdasarkan pengujian Intelligibility dari responden JBI, variasi kalimat uji a memiliki tingkat keakurasian tertinggi yaitu sebesar $100 \%$. Hal ini menunjukkan bahwa variasi kalimat uji A yaitu seluruh kata yang ada pada kalimat dieja satu-satu memiliki tingkat kejelasan yang sangat tinggi. Namun, pada kenyataannya sahabat tuli jarang menggunakan pengejaan pada komunikasi mereka.

3. Berdasarkan hasil pengujian Acceptability yang dilakukan, sebanyak 9 dari 10 kalimat yang diujikan terhadap responden tuli mendapatkan skor dengan range $75-99 \%$ yang berarti sebagian besar responden telah menunjukkan penerimaan yang baik atas gerakan isyarat yang dihasilkan oleh JASigning.

4. Berdasarkan hasil pengujian Acceptability terdapat satu kalimat yang masih memiliki tingkat penerimaan yang rendah padahal jika dilihat dari hasil pengujian Intelligibility tingkat kejelasan dan pemahaman dari responden sudah baik. Hal ini membuktikan bahwa pengujian Intelligibility belum cukup komperhensif untuk digunakan tanpa adanya tolak ukur lain.

5. Berdasarkan pengujian black-box, sistem dapat mengolah masukan pengguna dengan baik sesuai dengan format yang telah didefinisikan.

6. Berdasarkan seluruh hasil pengujian dapat disimpulkan bahwa sistem sudah dapat mengkonversi teks Bahasa Indonesia menjadi gerakan isyarat BISINDO menggunakan JASigning dengan baik serta memenuhi aspek Intelligibility dan Acceptability dengan hasil yang memuaskan. 


\section{REFERENSI}

[1] R. A. Mursita, "Respon Tunarungu Terhadap Penggunaan Sistem Bahasa Isyarat Indonesa ( Sibi ) Dan," Respon Tunarungu Terhadap Pengguna. Sist. Bhs. Isyarat Indonesa Dan Bhs. Isyarat Indones. Dalam Komun., 2015.

[2] B. Badan Perencanaan Pembangunan Nasional, B. Badan Pusat Statistik, and U. United Nations Population Fund, Proyeksi Penduduk Indonesia 2015-2045. 2018.

[3] S. Cox et al., "TESSA, a system to aid communication with deaf people," Annи. ACM Conf. Assist. Technol. Proc., pp. 205-212, 2002.

[4] T. Dasgupta and A. Basu, "Prototype machine translation system from Text-To-Indian Sign Language," Int. Conf. Intell. User Interfaces, Proc. IUI, no. January, pp. 313-316, 2008.

[5] K. Kaur and P. Kumar, "HamNoSys to SiGML Conversion System for Sign Language Automation," Procedia Comput. Sci., vol. 89, pp. 794-803, 2016.

[6] U. P. Tunarungu and A. N. Mansur, “*1), *2), *3) 1," vol. 6, no. 1, pp. 8-14, 2017.

[7] S. Prillwitz et al., "HamNoSys Version 2.0: Hamburg Notation System for Sign Languages:An Introductory Guide," International Studies on Sign Language and Communication of the Deaf. Signum Press, Hamburg, Germany, vol. 5, 1989.

[8] R. Elliott et al., "An Overview of the SiGML Notation and SiGML Signing Software System," In Fourth International Conference on Language Resources and Evaluation, LREC (pp. 98-104), 2004.

[9] Sugandhi, P. Kumar, and S. Kaur, "Online Multilingual Dictionary Using Hamburg Notation for Avatar-Based Indian Sign Language Generation System," Int. J. Cogn. Lang. Sci., vol. 12, no. 8, pp. 1116-1122, 2018.

[10] Elliott, R., Glauert, J.R.W., Kennaway, J.R., Marshall, I., and Safar, E., "Linguistic modelling and language processing technologies for avatarbased sign language presentation", Universal Access in the Information Society, vol. 6, no. 4, pp. 375-391, 2007.

[11] Freedman, A., "Computer Desktop Encyclopedia 9th Ed. 10,000 terms, 1,000 Illustrations," Penerbit Osborne/McGraw-Hill, 2001.

[12] Guntoro, E., "Development of Text-to-Speech for Malay Pontianak Dialect Based Hidden Markov Model with Phoneme," TELKOMNIKA, 2019.

[13] S. Seljan and I. Dunđer, "Automatic word-level evaluation and error analysis of formant speech synthesis for Croatian," In WSEAS European Conference of Computer Science, 2013.

[14] I. Pujihastuti, "Prinsip Penulisan Kuesioner Penelitian," CEFARS: Jurnal Agribisnis dan Pengembangan Wilayah, 2(1), 43-56, 2010.

[15] A. R. H. Bisjoe, "Menjaring Data dan Informasi Penelitian Melalui FGD (Focus Group Discussion):
Belajar dari Praktik Lapang,” Buletin Eboni, 15(1), 17-27, 2018 